\title{
In vitro Studies on Potentiation of Enrofloxacin by Phytochemicals
}

\author{
Srividya Gullapudi ${ }^{1 *}$, G. S. Rao ${ }^{1}$, P. Ravikumar ${ }^{1}$, Muralidhar Metta ${ }^{2}$ and V. Ramadevi ${ }^{3}$ \\ ${ }^{1}$ Department of Veterinary pharmacology \& Toxicology CVSC, Proddatur, \\ YSR Kadapa district, Andhrapradesh-516360, India \\ ${ }^{2}$ Department of Animal Genetics and Breeding, ${ }^{3}$ Dept of Veterinary Pathology, \\ SriVenkateswara Veterinary University, Tirupati, India
}

\section{A B S T R A C T}

\section{Keywords}

Enroloxacin,

Capsaicin,

Theobromine,

Efflux pump, MIC

Article Info

Accepted:

10 October 2020

Available Online:

10 November 2020
Enrofloxacin, an antimicrobial fluoroquinolone is most commonly used against majority of gram negative bacterial and mycoplasma infections in majority of livestock. Indiscriminate usage of enrofloxacin in clinical practice leads to resistance development to this quinolne drug. Among the various pathways of resistance, efflux pump mediated drug resistance is one of the important pathways identified in the recent past. Phytochemicals namely, theobromine, glycyrrhetenic acid and glycyrrhizic acid and capsaicin were identified as efflux pump inhibitors. Phytochemicals which possess efflux pump inhibitory activity if combined with classical antimicrobial agents reduces the development of resistance and also improves their therapeutic efficacy. Interaction between enrofloxacin, and capsaicin, theobromine, glycyrrhetenic acid and glycyrrhizic acid were studied by determining MIC and MBC against E.coli, S.aureus, K.pneumoniae and P.aureginosae following CLSI guidelines. There is a significant decrease in MIC and MBC values of enrofloxacin in the presence of phytochemicals. In conclusion, Synergisitic interaction of efflux protein inhibitory phytochemicals capsaicin, theobromine, glycyrrhetenic acid and glycyrrhizic acid with enrofloxacin was noticed in minimum inhibitory concentration (MIC) and minimum bactericidal concentration.

\section{Introduction}

Bacterial infections are one of the major clinical implications observed in routine veterinary practice. From the dawn of civilisation so many drugs, antibiotics came into role to treat bacterial infections. Even after the discovery of many antibiotics starting from penicillins to quinolones, treating the bacterial infections has became a challenging issue till to date due to the emergence of resistance by the bacteria to antibacterial agents. Antibiotics and other are used as growth promoters, coccidiostats and various purposes for the production of animal meat for human consumption.

Due to over the counter usage, indiscriminate application, failure of following the dosage regimen will sensitize the bacteria to develop resistance. Among several means of resistance development by the bacteria, efflux mediated resistance is of prime importance. 
Efflux proteins are present on bacterial cell membranes whose role is extrusion of the antibacterial agents inside the bacterial cell to outside, thereby enhancing their survivability (Borges Walmsley et al., 2003).

Antibiotic resistance is a one health challenge globally. de Kraker et al., (2016), reported that 10 million people will die due to AMR by 2050 , if the challenge was not encountered.

Enrofloxacin, a fluoroquinolone antimicrobial is effective against a broad spectrum of grampositive and gram-negative bacteria. Resistance has developed to this agent because of indiscriminate application (Adamson et al, 2015; Gouvea et al, 2015). It has also been reported that combination of putative efflux pump inhibitors trimethoprim and sertraline with levofloxacin resulted in enhanced therapeutic efficacy of levofloxacin a quinolone antimicrobial drug against P.aeruginosa that over expresses Nex-ABOprm, MexCD-OprJ and MexEF OprM efflux pumps (Adamson et al, 2015).

Perusal of available literature indicated that there are no reports of usage of phytochemicals that possess efflux inhibitory activity in combination with enrofloxacin to reduce its resistance to microbes are available.

Keeping the background in view, the present study was designed to determine the antibacterial action of enrofloxacin alone and in combination with phytochemicals capsaicin, theobromine, glycyrrhetenic acid and glycyrrhizic acid against $S$. aureus ATCC 25923, E.coli ATCC 25922, K. pneumoniae ATCC 700603 and $P$. aeruginosa ATCC 27853.

\section{Materials and Methods}

\section{Chemicals}

Enrofloxacin, Capsaicin, glycyrrhizic acid, glycyrhetenic acid and theobromine were procured from Sigma-Aldrich, St. Louis, MO, USA. Mueller-Hinton Broth was obtained from M/s Hi Media Laboratories Pvt. Ltd. Mumbai, India. Magnesium chloride was obtained from M/S Fisher Scientific, Mumbai, India and calcium chloride was from $\mathrm{M} / \mathrm{s} \mathrm{SD}$ Fine - Chem Ltd, Mumbai, India. $p$ Iodonitrotetrazolium (INT) was procured from M/s SRL, Mumbai, India. S. aureus ATCC 25923, E. coli ATCC 25922, $K$. pneumoniae ATCC700603 and P. aeruginosa ATCC27853 cultures were procured from Principal investigator, RKVY project, Dept of Veterinary pharmacology and toxicology, NTR CVSc, Gannavaram, SVVU.

\section{Determination of Minimum Inhibitory Concentration (MIC)}

\section{Preparation of 0.5 McFarland turbidity standards}

Stock solutions of $0.18 \mathrm{M}(0.36 \mathrm{~N}) \mathrm{H}_{2} \mathrm{SO}_{4}$ $(1 \% \mathrm{v} / \mathrm{v})$ and $0.048 \mathrm{M} \mathrm{BaCl}_{2}(1.175 \% \mathrm{w} / \mathrm{v}$ $\left.\mathrm{BaCl}_{2} \cdot 2 \mathrm{H}_{2} \mathrm{O}\right)$ were prepared. With a constant stirring to maintain a suspension, $0.5 \mathrm{~mL}$ of the $\mathrm{BaCl}_{2}$ solution was added to $99.5 \mathrm{~mL}$ of the $\mathrm{H}_{2} \mathrm{SO}_{4}$ stock solution. The correct density of the turbidity standard was verified by measuring absorbance using a spectrophotometer with a $1 \mathrm{~cm}$ light path and matched cuvettes. The absorbance at $625 \mathrm{~nm}$ was 0.08 to 0.13 for the 0.5 McFarland standard. $5 \mathrm{~mL}$ aliquots of $\mathrm{BaSO}_{4}$ were transferred into screw cap tubes of the same size as those used for standardizing the bacterial inoculum (CLSI, 2012).

\section{Preparation of supplements and media cation stock solutions}

Stock solution of $10 \mathrm{mg}$ of $\mathrm{Mg}^{++} / \mathrm{ml}$ was prepared by dissolving $8.36 \mathrm{~g}$ of $\mathrm{MgCl}_{2} \cdot 6 \mathrm{H}_{2} \mathrm{O}$ in $100 \mathrm{ml}$ of deionized distilled water and stock solution of $10 \mathrm{mg}$ of $\mathrm{Ca}^{++} / \mathrm{ml}$ was prepared by dissolving $3.68 \mathrm{~g}$ of $\mathrm{CaCl}_{2} \cdot 2 \mathrm{H}_{2} \mathrm{O}$ 
in $100 \mathrm{ml}$ of deionized distilled water. They were sterilized by membrane filtration and stored at 2 to $8^{\circ} \mathrm{C}$ (CLSI, 2012).

\section{Preparation of Cation-Adjusted Muller- Hilton Broth (CAMHB)}

Two hundred ml of Muller-Hilton Broth was prepared according to manufacturer's recommendations, autoclaved and chilled overnight at 2 to $8^{\circ} \mathrm{C}$. To this chilled broth, $0.2 \mathrm{ml}$ of $\mathrm{MgCl}_{2}$ stock solution was added with constant stirring followed by addition of $0.4 \mathrm{ml}$ of $\mathrm{CaCl}_{2}$ stock solution so that the final concentration of $\mathrm{Mg}$ and $\mathrm{Ca}$ ions in the broth was 10 and $20 \mathrm{mg} / \mathrm{l}$, respectively. The $\mathrm{pH}$ of the broth after addition of cations was 7.2 to 7.4 .

\section{MIC by broth microdilution method}

The broth microdilution method was used to determine the MIC of enrofloxacin against S.aureus ATCC 25923, E. coli ATCC25922, $K$. pneumoniae ATCC700603 and $P$. aeruginosa ATCC27853. Working standard of $1 \mu \mathrm{g} / \mathrm{ml}$ enrofloxacin was prepared by diluting the stock solution with normal saline. Two-fold serial dilution of enrofloxacin in CAMHB was prepared in 96 well microtiter plate, so that final volume in each well was $100 \mu \mathrm{l}$. The bacterial culture incubated in CAMHB at $37 \pm 1^{\circ} \mathrm{C}$ for 6 to $8 \mathrm{~h}$ was taken and its turbidity was adjusted to 0.5 McFarland turbidity standard (1 $\mathrm{X} \quad 10^{8}$ $\mathrm{CFU} / \mathrm{ml}$ ) which was then diluted $1: 20$ in CAMHB. When $0.01 \mathrm{ml}$ of this suspension was inoculated into the broth, the final concentration of bacteria was approximately 5 X $10^{5} \mathrm{CFU} / \mathrm{ml}$ (range $2-8 \mathrm{X} 10^{5} \mathrm{CFU} / \mathrm{ml}$ or 5 $\mathrm{X} 10^{4} \mathrm{CFU} /$ well). Each plate was sealed properly to prevent drying during incubation. Inoculated microdilution trays were then incubated at $35 \pm 2^{\circ} \mathrm{C}$ for 16 to $20 \mathrm{~h}$ in an ambient air incubator.

\section{MIC End Point}

The MIC is the lowest concentration of antimicrobial agent that completely inhibits growth of the organism in the microdilution wells as detected by the unaided eye or microplate reader (Multiskan ${ }^{\mathrm{TM}} \mathrm{GO}$, Thermofisherscientific ${ }^{\mathrm{TM}}$ ) to discern growth in the wells.

The amount of growth in the wells containing antimicrobial agent was compared with that of growth-control wells (no antimicrobial agent) used in each set of tests. Alternatively, bacterial growth and inhibition was detected by adding $25 \mu \mathrm{l}$ of INT to each well and incubation for $30 \mathrm{~min}$ at $35 \pm 2{ }^{\circ} \mathrm{C}$. INT is reduced to a red formazan compound by biologically active organisms. Bacterial growth was considered to be inhibited when the solution in the well remained clear. Solvent controls and growth controls were included in each experiment (CLSI, 2012).

\section{Determination of Minimum Bactericidal Concentration (MBC)}

The minimum concentration of the drug required to kill $>99.9 \%$ viable organism after incubation for a fixed length of time $(24 \mathrm{hr})$ under a given set of conditions is known as minimum bactericidal concentration (MBC). The wells that didn't show any visible growth of the organism on MIC microtiter plate were transferred to Meuller Hilton Agar. Then, the plate was incubated for 24 hours at $37^{\circ} \mathrm{C}$ (CLSI, 2012). MBC values were taken at the lowest concentration that does not show any growth in subculture agar.

\section{Results and Discussion}

The mean MIC, MBC values of enrofloxacin alone and in the presence of phytochemicals were depicted in table 1 and 2 . 
Table.1 Minimum Inhibitory Concentration (MIC, $\mu \mathrm{g} / \mathrm{ml})$ ) of enrofloxacin alone and in combination with efflux protein inhibitors against the selected bacteria

\begin{tabular}{|c|c|c|c|c|}
\hline $\begin{array}{c}\text { Name of the test } \\
\text { compound }\end{array}$ & $\begin{array}{c}\text { S. aureus } \\
\text { ATCC25923 }\end{array}$ & $\begin{array}{c}\text { E. coli } \\
\text { ATCC25922 }\end{array}$ & $\begin{array}{c}\text { K. pneumoniae } \\
\text { ATCC700603 }\end{array}$ & $\begin{array}{c}\text { P. aeruginosa } \\
\text { ATCC27853 }\end{array}$ \\
\hline $\begin{array}{c}\text { Enrofloxacin } \\
\text { Capsaicin + } \\
\text { Enrofloxacin }\end{array}$ & 0.202 & 0.020 & 1.650 & 2.433 \\
\hline $\begin{array}{c}\text { Theobromine+ } \\
\text { Enrofloxacin }\end{array}$ & 0.090 & 0.012 & 0.266 & 0.404 \\
\hline $\begin{array}{c}\text { Glycyrrhetenic acid } \\
\text { + Enrofloxacin }\end{array}$ & 0.041 & 0.012 & 0.012 & 0.450 \\
\hline $\begin{array}{c}\text { Glycyrrhizic acid+ } \\
\text { Enrofloxacin }\end{array}$ & 0.11 & 0.012 & 0.404 & 0.450 \\
\hline \begin{tabular}{c} 
Encin \\
\hline
\end{tabular} & & & & 0.450 \\
\hline
\end{tabular}

The values are expressed as mean of six replications

Table.2 Minimum Bactericidal Concentrations (MBC, $\mu \mathrm{g} \cdot \mathrm{ml}^{-1}$ ) of Enrofloxacin alone and in combination with Efflux protein inhibitors against the selected bacteria

\begin{tabular}{|c|c|c|c|c|}
\hline $\begin{array}{c}\text { Name of the test } \\
\text { compound }\end{array}$ & $\begin{array}{c}\text { S. aureus } \\
\text { ATCC25923 }\end{array}$ & $\begin{array}{c}\text { E. coli } \\
\text { ATCC25922 }\end{array}$ & $\begin{array}{c}\text { K. pneumoniae } \\
\text { ATCC700603 }\end{array}$ & $\begin{array}{c}\text { P. aeruginosa } \\
\text { ATCC27853 }\end{array}$ \\
\hline $\begin{array}{c}\text { Enrofloxacin } \\
\begin{array}{c}\text { Capsaicin+ } \\
\text { Enrofloxacin }\end{array}\end{array}$ & 0.403 & 0.040 & 3.300 & 4.867 \\
\hline $\begin{array}{c}\text { Theobromine+ } \\
\text { Enrofloxacin }\end{array}$ & 0.220 & 0.024 & 0.532 & 0.808 \\
\hline $\begin{array}{c}\text { Glycyrrhetenic } \\
\text { acid+Enrofloxacin }\end{array}$ & 0.081 & 0.024 & 0.808 & 0.900 \\
\hline $\begin{array}{c}\text { Glycyrrhizic } \\
\text { acid+Enrofloxacin }\end{array}$ & 0.220 & 0.024 & 0.808 & 0.900 \\
\hline The & & & & 0.900 \\
\hline
\end{tabular}

The values are expressed as mean of six replications

The interaction of enrofloxacin and enrofloxacin with efflux protein inhibitors viz. capsaicin, glycyrrhizic acid, glycyrrhetenic acid and theobromine with regards to MIC and $\mathrm{MBC}$ was explored against $E$. coli ATCC 25922, S. aureus ATCC 25923, $K$. pneumoniae ATCC 700603 and $P$. aeruginosa ATCC 27853 strains and were tabulated in table 1 and 2 . The MIC value of enrofloxacin was $0.02 \mu \mathrm{g} . \mathrm{ml}^{-1}$ against $E$. coli ATCC 25922 that was lowered $(0.012$ $\mu \mathrm{g} . \mathrm{ml}^{-1}$ ) in presence of capsaicin, glycyrrhizic acid, glycyrrhetenic acid and theobromine resulting in 40\% improvement in MIC against
E. coli. The MIC value of $0.2 \mu \mathrm{g} \cdot \mathrm{ml}^{-1}$ for enrofloxacin alone was observed against $S$. aureus ATCC 25923 which was lowered by $55 \%$ in the presence of capsaicin and $45 \%$ in presence of glycyrrhizic acid, glycyrrhetenic acid and theobromine. Similarly, it was shown that capsaicin potentiates enrofloxacin against $S$. aureus due to the inhibitory effect on NorA efflux pump of S.aureus (Kalia et al., 2012). The MIC value of enrofloxacin against $K$. pneumoniae ATCC 700603 was $1.650 \mu \mathrm{g} . \mathrm{ml}^{-1}$ which was reduced by $83.8 \%$ in the presence of capsaicin and was reduced to $75 \%$ in the presence of glycyrrhizic acid, 
glycyrrhetenic acid and theobromine. The MIC value of enrofloxacin against $P$. aeruginosa ATCC 27853 was $2.433 \mu \mathrm{g} \cdot \mathrm{ml}^{-1}$ which was reduced to $83 \%$ in the presence of capsaicin, glycyrrhizic acid, glycyrrhetenic acid and theobromine. It was also reported that phytochemicals like plumbagin, NDGA, and shikonin were able to increase susceptibility of bacterial organisms to antibiotics and toxic compounds and were also the most efficient in inhibiting AcrBmediated substrate efflux in bacteria (OheneAgyei et al., 2014).

The MBC value of enrofloxacin against E.coli ATCC 25922 was $0.041 \mu \mathrm{g} \cdot \mathrm{ml}^{-1}$. The MBC values of enrofloxacin alone and in the presence of efflux protein inhibitors was presented in table 2. The MBC of enrofloxacin against E.coli was reduced to $0.024 \mu \mathrm{g} \cdot \mathrm{ml}^{-1}$ in the presence of capsaicin, glycyrrhizic acid, glycyrrhetenic acid and theobromine. The MBC value of enrofloxacin against S.aureus ATCC 25923 was 0.403 $\mu \mathrm{g} \cdot \mathrm{ml}^{-1}$, which was reduced to $0.181 \mu \mathrm{g} \cdot \mathrm{ml}^{-1}$ in the presence of capsaicin and to $0.220 \mu \mathrm{g} . \mathrm{ml}^{-}$ ${ }^{1}$ in the presence of glycyrrhizic acid and theobromine. The MBC value of enrofloxacin against K.pneumoniae ATCC 700603 was $3.300 \mu \mathrm{g} \cdot \mathrm{ml}^{-1}$ which was reduced to 0.532 $\mu \mathrm{g} . \mathrm{ml}^{-1}$ in the presence of capsaicin and was reduced to $0.517 \mu \mathrm{g} . \mathrm{ml}^{-1}$ in the presence of theobromine. The MBC value of enrofloxacin was reduced to $0.808 \mu \mathrm{g} . \mathrm{ml}^{-1}$ in the presence of glycyrrhizic acid and glycyrrhetenic acid. The MBC value of enrofloxacin against P.aeruginosa ATCC 27853 was $4.867 \mu$ g.ml ${ }^{-1}$ which was reduced to $0.808 \mu \mathrm{g} \cdot \mathrm{ml}^{-1}$ in the presence of capsaicin and to $0.900 \mu \mathrm{g} \cdot \mathrm{ml}^{-1}$ in the presence of glycyrrhizic acid, glycyrrhetenic acid and theobromine. The results together suggest that the presence of efflux protein inhibitors enhances the bactericidal effect, which may be due to their efflux protein inhibitory potential; as a result they indirectly increase the intracellular concentration of the antimicrobial agent.
Based on the above results it can be concluded that phytochemical s as such may not show antibacterial action comparable to antibiotic enrofloxacin, but in combination they enhanced the antibacterial activity which can be utilised to reduce the amount of antibiotic required to produce the therapeutic effect.it can reduce the resistance development as well as cost of therapy.

\section{References}

Adamson DH, Krikstopaityte V and Coote PJ. 2015. Enhanced efficacy of putative efflux pump inhibitor/antibiotic combination treatments versus MDR strains of Pseudomonas aeruginosa in a Galleria mellonella in vivo infection model. Journal of Antimicrobial Chemotherapy. 70 (8):2271-8.

Borges Walmsley MI, McKeegan KS and Walmsley AR. 2003. Structure and function of efflux pumps that confer resistance to drugs. The Biochemical journal 376:313-38.

deKraker ME, Stewardson AJ and Harbarth S. 2016. Will 10 million people die a year due to antimicrobial resistance by 2050? PLoS Med. 13: e1002184

Gouvea R, dos Santos HC, de Aquino FF and Pereira AVL de. 2015. Fluoroquinolones in industrial poultry production, bacterial resistance and food residues: a review Brazilian Journal of Poultry Science Rev. Bras. Cienc. vic. vol.17 no.1 Campinas.

Kalia NP, Mahajan P, Mehra R, Nargotra A, Sharma JP, Koul S and Khan IA. 2012. Capsaicin, a novel inhibitor of the NorA efflux pump, reduces the intracellular invasion of Staphylococcus aureus. Journal of Antimicrobial Chemotherapy 67:24012408.

NCCLS. National Committee for Clinical Laboratory Standards, Approved standard M7-A5. 2000. Methods for 
dilution antimicrobial susceptibility tests for bacteria that grow aerobically. 5. ed. NCCLS, Wayne.

Ohene-Agyei T, Mowla R, Rahman T and Venter H. 2014. Phytochemicals increase the antibacterial activity of antibiotics by acting on a drug efflux pump. Microbiology open 3(6):885896.

Solomon SL and Oliver KB.2014. Antibiotic resistance threats in the United States: stepping back from the brink. Am Fam Physician. 15; 89(12): 938-4.

\section{How to cite this article:}

Srividya Gullapudi, GS. Rao, P. Ravikumar, Muralidhar Metta and Ramadevi, V. 2020. In vitro Studies on Potentiation of Enrofloxacin by Phytochemicals. Int.J.Curr.Microbiol.App.Sci. 9(11): 1053-1058. doi: https://doi.org/10.20546/ijcmas.2020.911.123 